\title{
Sciendo
}

\section{Alone in the Country of the Catholics: Labrador Inuit in Prague (1880)}

\author{
MARKÉTA KŘíŽOVÁ
}

Center for Ibero-American Studies

Charles University, Prague, Czech Republic

Institute of Contemporary History, The Czech Academy of Sciences, Czech Republic marketa.krizova@ff.cuni.cz

\begin{abstract}
The ethnographic shows of the end of the $19^{\text {th }}$ century responded to an increased hunger for the exotic, especially among the bourgeois classes in Europe and North America, and to the establishment of both physical and cultural anthropology as scientific disciplines with a need for study material. At the same time they served as a manifestation of European superiority in the time of the last phase of colonialist thrust to other continents. "Scientific colonialism" reached also to regions without actual colonial or imperial ambitions, as the story of Labrador Inuit who visited Prague during their tour of Europe in November 1880 will prove. The reactions of local intellectuals and the general public to the performances of the "savages" will be examined in the context of the Czech and German nationalist competition and the atmosphere of colonial complicity. Thanks to the testimony of a member of the group, Abraham Ulrikab, supplemented by newspaper articles and other sources, it is possible to explore the miscommunication arising from the fact that the Inuit were members of the Moravian Church, professing allegiance to old Protestant tradition in the Czech Lands and cultivating a fragmented knowledge of Czech history and culture.
\end{abstract}

KEY WORDS: ethnographic shows, history of anthropology, Labrador Inuit, Abraham Ulrikab, Moravian Church, Czech Lands, 19th century 


\section{Introduction}

In autumn 1880, a group of eight Inuit (or, as they were commonly denominated at that time, Eskimos $^{1}$ ) from Labrador set out for a tour through Western Europe, after being hired by Johan Jacobsen, impresario of the Hamburg entrepreneur Carl Hagenbeck. Passing through Hamburg, Berlin and Prague, they staged scenes from everyday life in the North, drove dogsleds, paddled kayaks and even speared live seals obtained exclusively for that purpose, receiving enthusiastic responses from plentiful audiences. They also underwent repeated examinations by physicians and anthropologists and produced handicraft "souvenirs" for private and public collections. However, after leaving Prague for the German cities of Frankfurt, Darmstadt and Crefeld, they one by one succumbed to a sudden illness that was finally identified as smallpox. The last of the Inuit died in Paris in January 1881.

The sequence of events is well known and the unhappy history of the Inuit group has already been reflected upon by historians and anthropologists. One reason is the existence of unusually rich repertoire of primary sources. Not only was this ethnographic show documented continuously by the press and reflected upon in scientific articles, but the impresario Jacobsen and one of the Inuit, Abraham, kept diaries (JACOBSEN 2014, ULRIKAB 2005). Abraham's text especially represents a rare testimony. ${ }^{2}$ The fact that the physical remains of the Inuit were after their death deposited in the museums in Berlin and Paris, and have so far not been repatriated, makes the study of the case the more topical. ${ }^{3}$

The present article aims to explore in more detail one part of the story, the two-week stay of the Inuit in Prague, and to use it as a stepping stone for more general considerations regarding the attitude of the inhabitants of the Czech Lands towards the faraway lands. Debates about

$1 \quad$ When quoting from the primary sources, I will leave this version of the ethnonym in the original version, even though in standard scholarly writing of today it is not acceptable.

2 Abraham wrote in his native Inuktitut; after his death the diary was shipped back to Labrador, where one of the Moravian missionaries translated it into German. The original was lost, but the German translation was preserved in Moravian Archives in Bethlehem, Pennsylvania. It resurfaced when Canadian ethnologist James Garth Taylor published a brief outline of the story of the eight Inuit in Europe (TAYLOR 1981). For other testimonies of the participants of ethnic shows see HERBSMEIER 1994; GOUAFFO 2013.

3 In June 2013, Canadian Prime Minister Stephen Harper and French President Francois Hollande signed a memorandum on "Canada-France Enhanced Cooperation Agenda" and also professed a commitment to "work with the appropriate authorities to help to repatriate Inuit bones from French museum collections to Canada". (RIVET 2014:19) But so far the repatriation was not put into practice. As well as the publication by Rivet, there is also a recent documentary film, Trapped in a Human Zoo (2016, CBC Television). 
the "margins of colonialism" have been going on for some time already in various national and regional historiographies in those parts of the world, both in and out of Europe, that were not directly involved in colonial expansion. That colonialism was not just a bilateral relationship between the metropole and the subdued (overseas) region may seem self-evident. However, the specificities of the ways in which certain groups of Europeans have constructed their identity/identities based on an encounter, real or imagined, with the non-European "Other" in the absence of an actual colonial enterprise deserves further exploration.

The commercial exhibitions of "savages" in Europe and North America throughout the $19^{\text {th }}$ and early $20^{\text {th }}$ centuries are nowadays often seen by historians as an effort to legitimize and celebrate the dominance of specific European nations, or Europe as such, over the rest of the world. This interpretation, however, provokes a need to explore the specificities of ethnographic shows in regions and societies that for various reasons lacked, or lagged behind in acquiring, colonial possessions even though their inhabitants were certainly informed about, and sometimes profiting from, the colonial endeavours of other nations. Besides, the unique coincidence of the "savage" Inuit in fact professing allegiance to the ancient Protestant denomination, the Unity of Brethren (Moravian Church), established in the $15^{\text {th }}$ century in the Czech Lands, and the way this fact was - and also was not - reflected by the Czechs themselves, will be discussed.

\section{Colonial Aspirations and the Inuit Performances}

The phenomenon of ethnographic shows or human zoos of the end of the $19^{\text {th }}$ century was a response to the increased hunger for the exotic, especially among the bourgeois classes in Europe and North America, and at the same time to the establishment of physical and cultural anthropology as scientific disciplines with a need for study material. By offering their performers to renowned scientists as objects of study, the exhibitors added importance and value to the events and elevated them beyond mere commercial ventures. Last but not least, the shows were a manifestation of the European sense of superiority in the time of the last phase of colonialist thrust to other continents, an occasion for formulating notions of racial and cultural differences. And what is important, they offered a chance of symbolic 
"domination" over faraway regions as well as to the inhabitants of those parts of Europe that could not have actual colonial or imperial ambitions. ${ }^{4}$

This was also true of the Czech Lands. ${ }^{5}$ Landlocked, their inhabitants scarcely participated in overseas explorations and exploitations. Still, there were numerous and varied "colonial fantasies" 6 and taste for the exotic developed towards the end of the $19^{\text {th }}$ century. Already in 1878 the Hagenbeck company had brought a Nubian group to Prague; the show was covered extensively by the local press and apparently enjoyed high attendance (HERZA 2018:172178). An exhibition on South Africa, organized in 1880 in Prague by the physician Emil Holub also provoked a great response, even though this only exhibited stuffed animals and mannequins in native costumes arranged in scenes that allowed a glimpse of "real life" in Africa, and not live entertainers (ŠÁMAL 2013). Holub in fact, during his lectures accompanying the exhibition voiced the conviction that Czechs should aspire to colonial settlement in Africa, "for their benefit and that of the natives" (ROZHOŇ 2005:64-65). ${ }^{7}$

There was one specificity in the attitude towards the non-European natives that came to the fore in the Czech Lands, brought about by the nationalist competition of this period. The Czech Lands were, from at least the Middle Ages, inhabited not only by the speakers of Czech, one of the Slavic tongues, but also by speakers of German. These "Bohemian German" (Deutsch-Böhme; the surname "Sudeten-Deutche" came only later) developed their own specific identity, considering themselves a group apart from other Germans. After hundreds of years of the relatively peaceful coexistence of Czech and German speakers, in the second half of the $19^{\text {th }}$ century the birth of nationalist sentiments caused an ostentatious

For ethnographic shows in general, see BLANCHARD - LEMAIRE - DEROO 2012; the specific case of Carl Hagenbeck as leading protagonist of these appears in AMES 2008.

The names Czech Lands/Lands of the Bohemian Crown denote the regions of Bohemia, Moravia, and Silesia, historically ruled by the kings of Bohemia and from 1526 incorporated into the Habsburg monarchy. In 1918 these lands became, together with Slovakia and Ruthenia, parts of the new Czechoslovak Republic. Throughout the 19th and early 20th centuries, the words "Czech" and "Bohemian" were often used as synonyms in English-language texts, while the phrase "Czech Lands" did not exist during that time; it is a product of the effort of present-day historians to grasp the territorial-social-cultural integrity of the region (for the various toponyms see DICKINS 2011; for the history of the Czech Lands see PÁNEK - TŮMA 2018).

The term "colonial fantasies" was coined by Susanne Zantop with respect to German society before it entered imperial and colonial competition (ZANTOP 1997); while the Czech case was in some respects different, the basic features of the directly and indirectly formulated notions of civilizational superiority and the somewhat "natural" right of colonial dominance were very similar to the German case.

7 For the Czech "colonial fantasies" in general see LEMMEN 2013. 
political, economic, social, and cultural separation of the two camps. Each produced its own literature, theatre, music, and scientific discourse; both sought self-identification via the stereotypic images of others - models to follow, or deterrent examples to be despised (HOUŽVIČKA 2016; COHEN 2006). Of course, these two groups did not encompass the whole of the population. There was certainly a great number who felt nationally indifferent, even though by the very end of the century when, following what were known as the Badeni ordinances (1897) that put the Czech and German languages on an equal level as official languages of Bohemia, the population of Prague especially was drawn into the clashes of popular nationalism (GLASSHEIM 2005:74-75). Before the 1890s, it tended to be the upper and middle classes who consciously formulated their national allegiance.

In their effort to prove they could qualify as a fully-fledged and civilized nation, and especially that they were capable of competing with the Germans in every field of intellectual and cultural activity, the Czechs pursued scientific research, established terminology, and published or translated specialized treatises. Interestingly enough, similar ambitions were manifested by Bohemian German scientists. Germans had actually begun to lose the upper hand in politics and economy in the Czech Lands from the 1880s, a fact resented and widely commented on by its representatives. Thus, they also struggled to prove their high intellectual status - not their parity with the main body of German culture and civilization, but rather the fact that even though they pertained to it, they were a group apart (ASCH - SURMAN 2012). ${ }^{8}$ It is against this background of nationalist intellectual competition that we have to read the beginnings of scientific interest in non-European lands and peoples and also the popular responses to the ethnographic shows and exhibitions in general, and the reactions of the Prague public to the Inuit performances in particular.

Arriving in Prague on November 12, 1880, the Inuit were accommodated for two weeks with Kaufmann's Menagerie, another popular show that exhibited various kinds of exotic animals to paying audiences. Jacobsen wrote in his diary for November 15, 1880: "Arrived in Prague in the evening. In Prague, our Eskimos were in Kaufmann's Menagerie. [...] The working time for the Eskimos was from 11 to 12, 3 to 4, and 6 to 8 o'clock in the evening. Visitors (numbers) in Prague were not bad, only that staying in a menagerie is anything but comfortable - after all, you are dealing with menagerists. [...] Since the Eskimos had never been shown in Prague before, the interest was quite strong. The press especially showed a in the first decade of the 20th century (KŘížOVÁ 2017). 
lively interest in us" (JACOBSEN 2014:61). The newspaper articles gave the performers magnanimous epithets such as "our guests from the North, who honoured Europe by their visit". ${ }^{9}$ But their accommodation in between the cages and their display to the public on a podium constructed originally for shows with elephants ${ }^{10}$ manifested clearly that they were in fact perceived as barely elevated above the beasts. The menagerie was allocated an undeveloped area "beyond the old Horse Gate", that is, beyond the upper end of present-day Wenceslaus Square, roughly on the site where only few years later the imposing edifice of the National Museum was to be built. ${ }^{11}$

As in Berlin, where the show stopped before arriving to Prague, the highlight of the stay was a staged hunt. A live seal had been brought from Holland, released into a pond in the park not far from the menagerie and the Inuit were told that they could have it for food if they caught it with a harpoon. The event was amply commented on in the newspapers, and Abraham also made some notes in his diary: "Have caught a seal in Prague in a pond, while there were enormously many people, yes indeed countless. When I harpooned it with the seal harpoon, everybody clapped their hands greatly like the eider ducks. When I was done with it, the voice makers sang greatly with violins, drums, trumpets, and flutes" (ULRIKAB 2005:45; also JACOBSEN 2014:61). The newspaper reporters commented more eloquently, describing the "frolicking" of the seal and the complicated manoeuvres of the three kayaks before the final blow was struck. But the reports also assumed a mocking tone, hinting at the deep cultural difference between the protagonists and the spectators, especially when announcing the aftermath of the hunt: "In the evening a celebratory feast will be held, with the main course consisting of larded seal roast. Bon appétit!" 12

The principle of the ethnographic show was to create among the paying audience the illusion of realizing one's own research, of the exploration of peoples unknown and hitherto unseen by Europeans. The notion of authenticity (das Echte) was the central idea around which the Hagenbeck shows evolved - therefore it was important that whole families were hired to

$9 \quad$ Národní listy $17-\mathrm{XI}-1880$, p. 3 (most of the newspaper articles that will be quoted were anonymous and without headings).

10 "The Eskimos were invited from their residences to the elephant-podium and here introduced to the public", reported Prager Tagblatt on 23-XI-1880, p. 2.

11 The location given in the advertisements in Národní listy, 15-X-1880, p. 4.

12 Národní listy $28-\mathrm{XI}-1880$, p. 3. The seal hunt was described in a very similar way in Prager Tagblatt, 26-XI-1880 (Beilage), pp. 4-5; reports from the daily performances for example in Prager Tagblatt, 17-XI-1880, p. 5, Prager Tagblatt, 19-XI-1880, p. 4, Národní listy 17-XI-1880, p. 3. 
perform, to bolster the claim that real everyday life was exhibited (AMES 2008:71). In Prague as elsewhere during their show, the "exploration" of the Labrador performers by eager visitors was massive, and even more stressful to the Inuit, not used to crowded spaces and intimate communication with unknown people, than to some other groups. Abraham complained in his diary, precisely in the part dedicated to the stay in Prague, of a constant stream of curious attendees who were entering the habitation and disturbing the privacy of his family even at times in between the performances, to such extent that "to talk to each other was impossible because of the many voices" (ULRIKAB 2005:45). At the same time, the impresarios in their informative brochures and verbal commentaries to shows, as well as the newspaper articles, identified beforehand what the visitors should look for, building on the already established clichés and stereotypes of the specific non-European ethnic groups. Lamentably, we do not have any testimony of how the visitors themselves saw the Inuit, as was the case of some later shows (KŘÍŽOVÁ 2020), but the images imparted by the newspaper articles both in Czech and in German were explicit.

Of the stereotypes attached to the "guests from the Far North", the most often reflected upon was their alleged filthiness. An article in one of the social journals, aspiring to give the readers a general "ethnographic overview" of the Inuit in Labrador, asserted: "The Eskimos never wash their cooking vessels. This work they delegate to their dogs. Those of them who themselves somehow are aware of their own filthiness make things even worse; as when entertaining a distinguished guest, they lick the piece of meat to be served to him, to deprive it of blood and filth from the pot. To fail to accept thankfully would make one discourteous and impolite. [...] Their dress is covered with grease, filth and swarming with vermin." 13 The article continued by explaining that this lack of cleanliness was in fact caused by the lack of water especially in winter months; but the filthiness was duly noted also in the case of the Inuit visiting Prague who could not complain of the unavailability of water. ${ }^{14}$ The "ugliness" of the Inuit, men and women alike, was accentuated and explicitly compared with the European standard of beauty, even though at times the "deepest state to which humans can fall" was ascribed to the everyday merciless fighting for survival in the extreme conditions of the North. ${ }^{15}$ Interestingly, while the term "Eskimo race" was sometimes used in the

13 Světozor 26-11-1880, p. 570.

14 Prager Tagblatt, 17-XI-1880, p. 5.

15 For example, the Prager Tag-Blatt, 10-XI-1880, pp. 1-2, announced the visit of "exotic guests" but soothed the readers by stating that, unlike the visits of Goethe or Casanova to the city, these would not present any "danger" to their wives and daughters. 
newspaper articles, ${ }^{16}$ the description of physical characteristics was mostly brief and apparently without interest, or looking for similitudes rather than differences: "If their coarse black hair was not long and nicely combed, they would look like tanned Hungarian gypsies", stated one of the Czech articles. ${ }^{17}$ In contrast to other performers, for example the black Africans "observed" by the Prague burghers some time before and after (HERZA 2016b), the physical difference of the Inuit was mostly ascribed to cultural rather than biological terms.

One "ethnographic observation" made repeatedly by journalists and passed to the readers to verify was the Inuit style of clothing, especially the fact that female dress almost did not differ from male. ${ }^{18}$ And while the two families visiting Prague were composed of one man and his wife and children, the periodicals paid attention to the Inuit practice of polygamy and even polyandry, in a tone piquing the reader with respect to the moral principles of the times: "A strong or skilful man might have more than one woman; a beautiful or reasonable woman more than one man. Sometimes they borrow women for some time, a practice that renders advantages not only to one party. "19 But there were also similarities seen and commented on, among them the fact that the Inuit apparently loved their children just as tenderly as their "civilized" counterparts. ${ }^{20}$

Of course, the culinary preferences of the Inuit were also "explored" by visitors and journalists alike. The latter commented enthusiastically that the Inuit enjoyed Central European food - beef, rice, potatoes, and especially the Prague beer. ${ }^{21}$ Even though the adherence to beer-guzzling was at the time criticized by those Czech intellectuals who styled themselves cultured and progressive, for the majority of the Czech as well as the GermanBohemian population, beer-drinking remained an important national auto-identification marker. It was also an instrument of social interaction, as it preponderantly took place in restaurants and pubs, and was thus of great importance in the process of national revival (NOVOTNÝ 1997).

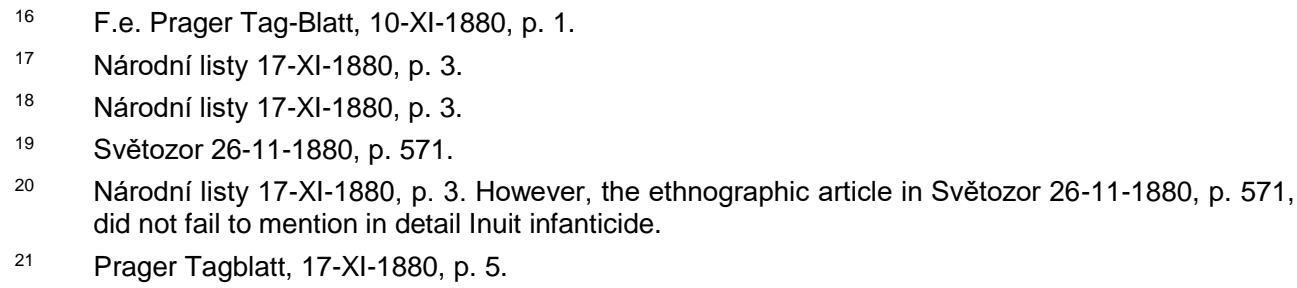

DOI: 10.2478/eas-2021-0010 @ University of SS. Cyril and Methodius in Trnava. All rights reserved. 
In line with the dominant imperialist discourse of nascent anthropology, the Inuit, old and young alike, were described as childlike, immature. And while newspaper reports noted the manifest "cheerfulness" of the performers, the general message passed on to the readers and visitors of the shows was not only that of an extremely primitive culture, but also of a culture doomed, "apathetic and incapable of a fight for existence, destined to perish according to Darwin's well-known theory. "22 In all this there is no marked difference between the reports in Czech and German-Bohemian periodicals. It was never even implied in the commentaries that, in reality, the two men who consented to bring their families to Europe did so on their own initiative, in an effort to ensure a better life for themselves and for their offspring, and that they proved repeatedly their courage and enterprising spirit by facing the unknown and threatening cultural clash. Instead, they were seen as the passive objects of external manipulation. When the newspaper articles wrote of "self-sacrifice" and "strenuous toil", they attached these epithets to Hagenbeck and Jacobsen, who "in spite of all obstacles and at great financial cost" brought the Inuit to Europe and thus made it possible for the Prague burghers to see them. ${ }^{23}$ The fact that the Inuit were "doomed", made the Prague performances the more attractive, as the spectators had probably the last opportunity to see them. Also, even though this was not stated openly, the image of the vanishing race presented an important mirror image to bolster the self-assurance of Czechs and Germans in the Czech Lands, who both thought of themselves as predestined to magnificence.

\section{Brethren in Faith and Their Enemies}

While advertised as "savages unspoiled by civilization", the Labrador Inuit in fact had been in contact with European explorers and traders for at least two centuries; their material and spiritual culture, social organization and mentality adjusting to trade as well as to armed clashes with various groups of white people. And what was even more important, five of the eight performers in Prague were Christians, members of a very specific church community that had its roots in the Czech Lands - the Moravian Church, or Unity of Brethren. It was established in the 1720s in Saxony, in the newly founded town of Herrnhut, by religious refugees from Moravia who claimed to be direct successors of the community of believers that arose in response to the Hussite wars of the $15^{\text {th }}$ century and was known as the Unity of 
Brethren. ${ }^{24}$ Immediately after its establishment, the Moravian Church launched a massive expansion, founding towns not only in many countries of Europe, but also in North America, and organizing them on the model of Herrnhut. At the same time, missions began among native groups in Greenland, the Caribbean, Pennsylvania and Ohio, South Africa and India (HAMILTON - HAMILTON 1967).

By the $19^{\text {th }}$ century, the Moravian Church had developed into a broad network of Ortsgemeinen (i.e. settlement congregations) and missionary stations across all the known world. Even though the religious enthusiasm abated somewhat in the course of time, the Church maintained its doctrine and its specific lifestyle. While participating eagerly in local economies, often transforming the mission stations even in far-away regions into booming artisanal and commercial centres, and communicating with people of various languages and cultures, the Moravians preserved their distinctiveness as a group, though ceremonies, festivals, use of specific codes, and the awareness of a specific, shared history. In this history their establishment in the Czech Lands, and the teachings of the famed bishop of the original Unity of Brethren, the philosopher Jan Amos Komenský/Comenius, assumed a prominent place in this history (MURPHY 1995).

The work in Labrador was begun by the Moravians in 1771 as an enlargement of the already existing mission stations in Greenland, by founding the first mission station, Nain, and later Okak (1776), Hopedale (1782) and Hebron (1830). It was precisely in Hebron that the family of Abraham was recruited by Jacobsen in 1880. During the late $19^{\text {th }}$ century additional mission stations were established so that the Moravian influence extended along the entire Labrador coast between Hamilton Inlet and Ungava Bay. By the second half of the $19^{\text {th }}$ century most of the Inuit inhabitants of Labrador embraced the Moravian faith, with the exception of several hundred who lived in the north. From the beginning of their work in Labrador the missionaries combined evangelical objectives with very lucrative trade (WHITELEY 1966).

In order to attract and then anchor the Inuit to the newly founded communities, the Moravians had to acquiesce to their demands for manufactured products, food items and raw materials - on which the Inuit were already dependent after a century of contact with the Europeans.

24 The members of the church that was established in Herrnhut referred to themselves originally as "brothers" and "sisters" and to their religious community Brüdergemeine (Unity of Brethren), which was the German translation of the Czech denomination of the original church - Jednota bratrská or its Latin version Unitas Fratrum; however, from the 1730s in the English-speaking world, the denomination "the Moravian Church" prevailed (LEMPA - PEUCKER 2010:21). 
Moreover, by supplying the desired goods, the missionaries undermined the authority of the traditional leaders and assumed an important position in native hierarchies (LORING 1998: 207-209). As the economic survival of the missions depended on the export of traditional produce, such as fish and seal blubber, the Moravians did not encourage the Inuit to change their lifestyle. ${ }^{25}$ Nevertheless, the missionaries had in their discourse accentuated to the extreme the dichotomy between the orderly, hard-working, cheerful converts of their mission villages and the "heathens" - the dirty, unkempt, feral, wandering Inuit hunters of the north of the Labrador coast. In fact, they presented the two groups almost as two different "nations". This image was then taken over by travel accounts, often taking the information from Moravian writings. It was also presented in the published commentaries to the 1880 show. ${ }^{26}$

Jacobsen had originally planned to employ only "true savages" - even though, as was explained above, the culture of the non-mission Labrador Inuit had also been deeply changed since the $17^{\text {th }}$ century - but could not persuade more to accompany him to Europe. He thus forced the family of Abraham to stage "primitive" life. For example, as the Moravian yearly report mentioned in 1876, the Inuit in Hebron no longer lived in igloos or sod huts, but in wooden houses with stoves: "The walls are papered with bright colours and adorned with pictures, and each house has its clock, mirror, and petroleum-lamp. [...] The clothing, too, has become European. "27 During the European tour, however, Abraham, Ulrike and their children had to live in the replica of the primitive hut and dress in furs, albeit with Europeanstyle underwear they could not be persuaded to remove. ${ }^{28}$

But the fact that some of the performers were Christians and "civilized" could not be disguised, so it was instead accentuated to bring more diversity to the show. To make the contrast even more prominent, the head of the second, "pagan" family, by the name of Terriniak, was presented as shaman (angakok). This cultural differentiation brought about another feature of the show to be appreciated by the spectators. As one of the Prague

25 One of the letters sent from Hebron and published in the inner journal of the Moravian Church, the Periodical Accounts, explained: "If we educate the Esquimaux youth after our fashion, we are sure to deprive them of the ability to procure their livelihood, in the only way that seems appointed for the dwellers of this coast" (Periodical Accounts 2 (1847), p. 123).

26 Such contrast between Christian and heathen Inuit for example in anon. 1871.

27 Report of the missionaries in Hebron, reprinted in the internal newsletter of the Moravian Church, Periodical Accounts 30 (1876), pp. 146-147.

28 The woollen shirts protruding from the seal furs worn by the performers were noted by Frankfurter Nachrichten, 3-XII-1880, quoted by RIVET 2014:50. 
journalists wrote, "the outer appearance and facial expression changes when the Eskimo renounces the vagrant life and becomes a settled citizen working under the protection of a missionary. The difference is so marked that no one would for a second hesitate to guess which of the Eskimos in the menagerie of Mr. Kaufmann is heathen and which is Christian. "29 For the entertainment of the visitors of his igloo at the menagerie, Abraham would write his name on a piece of paper and give it away. He could draw pictures, play the violin and spoke some German and English. All these strange talents of a "savage" astonished the visitors. ${ }^{30}$ Even more important was the religious devotion of Abraham and his family. In fact, Abraham was motivated for the journey to Europe not only with the promise of payment that would enable him to repay his debts and those of his late father, a debt to the Moravian store in Hebron (ULRIKAB 2005:3-5). He was also curious to visit the places of which he heard during sermons and in the mission school, and to meet some of the Moravian missionaries he knew who had since retired. He was promised a visit to Herrnhut in the end of his tour; this visit was in the end not realized due to the attack of smallpox. But even during the show's visit to Berlin several members of the church, including the missionary Elstner who used to work in Labrador, visited the family and invited them for a church service. ${ }^{31}$

It is not clear what the Inuit converts specifically knew about the Czech Lands. None of the missionaries at the Labrador stations was of Czech origin (since the $18^{\text {th }}$ century, the membership of the Moravian Church had grown in various parts of Europe) or familiar in any way with the region. They all spoke German or English as their mother tongue. But the Church continued to celebrate the death of Jan Hus, the famed church reformer of the $15^{\text {th }}$ century (on July 6), ${ }^{32}$ and the birthday of Comenius (March 28). Moreover, it seems that the Inuit, as well as other Moravian converts all over the world, were imparted the image of a mythical cradle where the Unity of Brethren came to existence. Three decades after the unfortunate tour of Abraham and his family to Europe, Czech tradesman Jiří Jaeger found employment at the mission stations of the Moravians in Labrador. In his autobiography he remembered the enthusiastic welcome from the Inuit and the questions they asked "about the

Národní listy 17-XI-1880, p. 3.

Světozor 26-11-1880, p. 570; Prager Tagblatt, 19-XI-1880, p. 4.

The visit was amply reported by the Moravian missionaries themselves (Periodical Accounts 1881, p. 523), and by Abraham (ULRIKAB 2005:7).

For this personality see FUDGE 2010. 
motherland of Jan Amos Comenius". Jaeger was also asked to speak in Czech, "so that the Eskimos knew the language of the great father of nations" (JAEGER 1963:20).

At the same time, however, the story of the Unity of Brethren before the rejuvenation in Herrnhut in the third decade of the $18^{\text {th }}$ century was that of oppression and persecution, and the Czech Lands were described to native converts all over the world as being the stage of this persecution, as land inhabited by the enemies of the true faith. Already in Germany, Abraham felt the sense of superiority of a true believer over those not yet enlightened. "Some Kablunat [= strangers] laugh at us, but this did not make us tired, as their souls are also to be laughed at," he noted in his diary while in Berlin (ULRIKAB 2005:26). Still, the plans to go to Prague unsettled him, and during the whole stay he was tense and frightened: "I am writing in Prague here far away, in Austria, in the country of Catholics, in a big city. We are here for two weeks, inside a big long house. To go out is impossible, so that we may not be caught by the Catholics. With a little voice [we] sing and pray to get help from the Lord, so that nothing happens to us through the Catholics, because they are always asking if we are believers; we are unable to deny and claim it constantly while we wonder if they will do us harm. Yes indeed, because everything is to be feared here, we feel that we need a lot of help" (ULRIKAB 2005:45).

As could be imagined, the visitors of the performances certainly had no vile plans with regard to the Moravian Inuit. For the Czech national revival of the $19^{\text {th }}$ century, whose protagonists celebrated the "traditional" Czech culture in contrast to the German one and at the same time promoted the re-establishing of state sovereignty, "liberation" from the Austro-Hungarian Empire, the remembrances of the original Unity of Brethren and the tradition of clandestine Protestantism acquired a very important role. Although the preponderant majority of the inhabitants of the Czech Lands indeed professed the Catholic religion, the opposition to it in the discourse of the Protestants of the $17^{\text {th }}$ and $18^{\text {th }}$ centuries was presented as a fight against Habsburg "oppression" and thus perceived positively by the patriotic Czechs of the 1880s. ${ }^{33}$ However, the founders of the renewed Unity of Brethren were German-speaking, while the Czech Protestant emigrants at the same period founded other communities elsewhere in Germany. Therefore, the story of this particular settlement did not fit into the story of Czech

33 The image of the clash between Protestantism and Catholicism as the principal theme of the history of the Czech Lands, and the inherently democratic spirit of Protestantism, was central in the foundational work of both Czech historiography and Czech nationalism, see e.g. PALACKÝ 1867. The image of Comenius in 19th century Bohemia and Moravia analysed in ŘEZNíKOVÁ et al. 2014. 
history as it was constructed in the $19^{\text {th }}$ century. ${ }^{34}$ Contact with the Czech Lands on the part of Herrnhut was minimal throughout the $18^{\text {th }}$ and most of the $19^{\text {th }}$ century. Only in the $1870 \mathrm{~s}$ several "choirs" (Choren) - the basic congregations of the Church - were established, mostly in German-speaking regions of Bohemia and Moravia, but these remained marginal as far as the number of members went, as well as the interest of the public. ${ }^{35}$ With regard to the Inuit show, the Czech media did not mention even once the fact that the mission from which Abraham's family came was that of the Moravian Church. Had they known it, the Czechs would certainly be interested in what the "savage" actually knew of the famed history of Czech Protestantism, but probably not welcome them as "brothers" of the same faith and shared heritage of one specific historical period.

\section{Czech-German Competition and the Inuit Bodies}

As was already mentioned, an interest in the non-European lands and their inhabitants had arisen in the Czech Lands too since the middle of the $19^{\text {th }}$ century. From the 1870 s the Náprstek Museum (Náprstkovo muzeum), an institution of distinctive origin and history, had constituted a centre for such proto-ethnographic research of the Czech community, while the German-Bohemians communicated with similar institutions in Vienna, Leipzig and Berlin.

The Náprstek Museum, founded in 1874, was originally devised as an industrial museum, similar to that in Kensington (today the Science Museum in London). Through documenting scientific and technological progress in the world, it was to assist Czech industrialists, at this period still marginalized by their German competitors, to develop their skills (MAJER 1994:16). However, from the beginning the industrial collections were supplemented by exotic souvenirs from all over the world. The founder of the museum, Vojta Náprstek, a Czech patriot enthusiastic for progress in both technical and social areas, brought some from his visit to North America in 1848-58. Further exhibits were supplemented by other Czech travellers and tourists. They were partly integrated into the collections as demonstrations of early developmental stages of various arts and crafts and as documentation of the progress which supposedly liberated Europeans, and especially women, from the bondage of

$34 \quad$ Herrnhut was described as an exclusively "German" town for example in the popular article by František Augustin Slavík "Ochranov (Herrnhut)", Světozor 6-XI-1874, p. 535.

35 In 1910, in the general census of Austro-Hungary, only 1013 persons in Bohemia and Moravia professed allegiance to this particular church (NEŠPOR 2010:215). 
exhaustive physical labour, and freed their minds for intellectual pursuits. But as the numbers of such artefacts increased, the original conception of an industrial museum was seriously disturbed, being transformed into a rather hybrid institution, the more so because "primitive" displays from Bohemia and Moravia were also included (such as embroideries and laces, under the denomination "Works of our Mothers") (SECKÁ 2011:211-213). Still, what developed in this setting can, with a certain exaggeration, be termed the initial phase of Czech anthropology, even though parochial, restricted in scope, lacking theory and developed in a haphazard manner.

What is extremely interesting in the context of the present text is the fact that Náprstek was in contact with Herrnhut. Ever since the $18^{\text {th }}$ century, the various exotic "souvenirs" that were brought from the missions were deposited in central institutions of the church. The most famous of these early collections was deposited in the college at Barby and later transferred to Niesky, also in Saxony. The objects were used as demonstrations in the process of preparing further missionaries and probably also for promotion of the mission work among the general public, to attract benefactors and influential patrons. Under the impact of the general increase in interest in anthropology and natural sciences in the course of the $19^{\text {th }}$ century, there were efforts to "professionalize" the collection. In 1878 out of the initiative of several prominent residents of Herrnhut, namely the apothecary Bernhard Kinne, the archivist Alexander Glitsch and the congregation elder Johannes Theodor Dobler, an association for the establishment of the museum was formed and efforts started to assemble the existing collections, acquire new ones from the mission fields and organize them for the display (MEIER 1978:5). ${ }^{36}$ Of course, the goal of the museum was not so much scientific, as promotional, a fact that was admitted and even accentuated in the correspondence of its founders. The ethnographic collections were to evoke the exotic settings of the mission stations and mitigate to the visitors the conditions of work of the brethren there. ${ }^{37}$

Apparently, the circular letter sent in 1879 by the would-be museum association to the Moravian missions in America, Africa and Asia was enthusiastically responded to, because in the next year, besides the fact that the museum halls indeed were opened in the "House of

36 Only in 1901, however, did the museum obtain its own building. Since 1975 the Völkerkundemuseum Herrnhut constitutes part of the Staatlichen Kunstsammlungen Dresden. See also NIPPA 2003.

37 This was how the aim pof the mission was explained in a second circular letter sent to mission stations by the museum committee. (Rundschreiben an die Brüder auf den Missionsstationen mit der Bitte um ethnographische Gegenstände zur Erweiterung der Sammlung, s.d. (1880), Archiv der Brüdergemeine, Herrnhut, fund Museums-Verein Herrnhut, box 1, no. 3). 
the Brethren" (Brüder-Haus) in Herrnhut, it there were also sales of the surplus displays, the profits taken over by the mission enterprise. This procedure is documented also in the two letters that were preserved from what apparently was a more extensive communication between Vojta Náprstek and Alexander Glitch (in March 1880. Glitch in these letters offered Náprstek some items from a "bazaar", brought from the missions in Jamaica, Surinam and also Labrador. In the end, Náprstek bought such objects as model of a kayak made of walrus ivory, one coat of fur and another of cloth, and a leather bag. ${ }^{38}$ Apparently, they were to serve precisely as examples of "primitive technologies" and attractions to visitors of the Prague establishment, without any allusions to the heritage of the old Unity of Brethren shared by the authors of the objects and the Czechs who came to see them displayed. In contrast, the visit of the Moravian Inuit in Prague did not rouse much interest in Náprstek and the associates of the museum.

There was one important aspect in which the Náprstek Museum differed from the nascent anthropological museums elsewhere in Europe and North America. These commonly included human remains among archaeological and ethnographical exhibits, while the founder and the affiliates of the Náprstek Museum, perhaps because of its original concept as an industrial museum, never demonstrated any interest in physical anthropology. Also, unlike their contemporaries in Germany and France, they did not actively seek the ethnographic shows in order to "study" the natives. While such performances were indeed advertised, also in Prague, as educative events, they apparently ignored them or maybe saw them as a vulgar, popular pastime (we found no reflection of any involvement in these in the detailed diaries and notes of Náprstek and his wife, while they commented on numerous other social and educational events taking place in Prague). ${ }^{39}$

There were some Czech physicians who visited ethnographic shows. ${ }^{40}$ There also had been some research in physical anthropology going on in Czech academia, mostly focusing on bolstering Czech national identity by proving the biological existence of a specific "Czech

38 The letters by Alexander Glitch to Náprstek, dated on March 7 and 11, 1880, in the Living Registry of the Náprstek Museum [Živá registratura NpM], fund Spisy dárců NpM, file Herrnhut. I am thankful to Gabriela Jungová, the curator of the North American collection of Náprstek Museum, for making me aware of the existence of this connection between Náprstek and Herrnhut.

39 On Náprstek's diary and that of his wife, see SECKÁ 2016, SECKÁ - ŠÁMAL 2014.

40 For example, Filip Herza mentions the official interest of the Association of Czech Physicians in the freak show Kosmos that came to Prague in 1901. On the occasion of the event was organized a special meeting in which the leading representatives of Czech medical science took part (HERZA 2018:165). 
type", distinct from but essentially equal with (or even superior over) the German population in the Czech lands. Together with ethnological research that brought proofs of cultural equality, such research was to give material proofs to further the aspirations of Czechs to independent statehood (GRÉGR 1858, cit. in HERZA 2016a:72). In 1904 Jindřich Matiegka was named the first "professor of demography and anthropology" at Charles University, pursuing further the research that, however, mostly did not extend to non-European anthropology. This area was left to the German scientists well into the $20^{\text {th }}$ century (ŠKERLJ - BOŽEK 1952).

As to the Inuit in 1880, they were, as was a general custom of the time with the performers at the ethnographic shows, also subject to anthropometric and medical investigation. In Berlin they were examined by the most prominent protagonist of physical anthropology of the times, Rudolf Virchow, who conducted a detailed physical and cranial measuring, asked questions about the eating habits of both families, and tested the ability of adults to count, and their colour perception. ${ }^{41}$ On November 7, 1880, an extraordinary meeting of the "Berlin Society of Anthropology, Ethnology and Prehistory" (Berliner Gesellschaft für Anthropologie, Ethnologie und Urgeschichte) was held at Berlin Zoological Garden in the presence of the Inuit. Rudolf Virchow gave a lecture in which he shared the results of his previous research on them (VIRCHOW 1880). Two weeks later, the same procedures were repeated in Prague, undoubtedly as part of the abovementioned effort of German-Bohemian intellectuals to prove their equality with their colleagues in Germany. Before the performances for the public started, on November 16, the professors of Charles University in Prague, Edwin Klebs and Carl Toldt, examined the Inuit. They also subsequently gave a public lecture on their findings.

The Prague physicians simply stated that they considered both Inuit families to be ideal representatives of a "primitive race". ${ }^{42}$ It is interesting that the conclusions reached by Rudolf Virchow were much more complex. After comparing the "heathen" and the "Christian" family, he considered their differing abilities to be products not of innate racial inferiority, but rather the lack of opportunity to develop intellectually, caused by the harsh climate (BAEHRE 2008).

Characteristically, the lecture on the Inuit that took place in Prague was held for the "Society of German Physicians in Bohemia" (Verein der deutschen Ärzte in Böhmen), thus excluding

41 Article published in the Charlottenberger Zeitung (2-XI-1880, p. 2) reported the examination took place on October 28, 1880.

42 Prager Tagblat, 21-XI-1880 (Beilage), p. 5.

DOI: 10.2478/eas-2021-0010 @ University of SS. Cyril and Methodius in Trnava. All rights reserved. 
the Czech intellectuals. ${ }^{43}$ The fierce nationalist competition in Bohemia and Moravia effectively blocked any cooperation between the intellectual leaders of the wo national groups.

The journalist of German-Bohemian (and also of Jewish) origin, Egon Erwin Kisch, described the absurd consequences: "The average German avoided any contact with the [Prague's] half-million Czechs other than strictly demanded by business. He never lit his cigar with a match from the Czech School Fund, while a Czech never used a match from the little box with the imprint of the German School Association. No German would let himself be seen in the Czech Citizens' Club, while no Czech was ever caught in the German casino. [...] If the Comédie Francaise or the Moscow Art Theater [...] gave a guest performance in the Czech National Theatre, the German press of Prague ignored it utterly" (KISCH 1941:80). Thus once the anthropological examination was taken over by German physicians, the Czech specialists in the same field in fact could not involve themselves (unless they wanted to jeopardize their social position in patriotic circles). As was explained above, in the 1880s the competition did not affect the lower classes and the sphere of popular entertainment so fundamentally. Kaufmann's Menagerie apparently pitched camp on neutral ground, so that both Czech and German visitors came to see the show and both Czech and German newspapers commented on the performances.

The Náprstek Museum also did not buy any of the artefacts that Jacobsen brought from Labrador, or those produced by the Inuits during their exhibition, to add to the recently acquired objects from Herrnhut. Only later, the Labrador collection increased considerably, thanks to the donations from the already quoted Jiří Jaeger, who worked for the Moravians in 1914-20. Also, there were contributions from Vojtěch Schuck/Suk, an anthropologist from Charles University who carried out his investigations in Labrador in the 1920s (KLÁPŠŤOVÁ 2015). This lack of interest in acquiring exotic artefacts from the 1880 show can be seen as another proof of the contempt among the circles of the Náprstek Museum for ethnographic "spectacles" that, however, suited the inclination of the general public, Czech and German-Bohemian alike. 


\section{Conclusion: The End of the Show}

Given the popularity of the show in Prague, it is not surprising that several Czech and German-Bohemian dailies also commented on its disastrous ending. The more so, because the funerals of the first two victims in Darmstadt and Krefeld turned into another type of ethnographic spectacle, as thousands of onlookers gathered at the cemeteries and observed how the Inuit would express their grief and how they would dress. In his diary Jacobsen noted that "[in Darmstadt] the burial took place at 40 'clock in the afternoon. It had been advertised among the public by the registrar's office, and on our arrival at the cemetery, we therefor found several thousands of curious people, who had come to see the burial" (JACOBSEN 2014:63). ${ }^{44}$

When in Paris smallpox was identified as causing the deaths, the gaze of German and French physicians turned to Prague as a possible source of the infection - even though originally it was supposed that the disease could have originated from the "antiquities" Jacobsen dug up at the cemetery near Hebron and demonstrated during the shows (JACOBSEN 2014:31). But such theories were soon abandoned. Indeed, in the last months of the year 1880 Prague suffered from unusually heavy smallpox epidemics (Ǩ̌ÍŽ - BENEŠ 2010:34). This the Czech and German-Bohemian newspapers did not deny; but that Prague was marked as "proverbial source of contagion" by the Paris physician Léon Colin ${ }^{45}$ provoked indignant responses from both. At the same time, the journalists made use of this amply commented on case to call on the "proper authorities" to act for the improvement of housing and hygienic conditions in the poorer quarters of Prague and to advocate the beneficial effects of vaccination that at this period was not yet accepted by all medical practitioners in the Czech Lands. In line with the previous descriptions of the "filthiness" of the Inuit, the articles also emphasized the beneficial effects of regular hygiene for preventing the spread of infectious diseases. $^{46}$

44 Descriptions of the funerals in Brünner Zeitung 24-XII-1880 (Beilage), p. 1179; Mährischschlesischer Correspondent 24-XII-1880, p. 4; summary of the deaths of all Inuit in Moravské noviny 25-I-1881, p. 3.

45 The presentation of León Colin on the disease, with Prague identified as the place of contagion, was done in front of the Academy of Medicine (Academie de Médécine) in Paris and subsequently published in Gazette Hebdomadaire de Médecine et de Chirurgie 18:8 (25-II-1881), p. 116.

46 Prager Tagblatt 9-III-1881 (Beilage), p. 5; Časopis lékařů českých 9-IV-1881, pp. 233-234, 16-IV1881, pp. 249-250. 
During the months when the Inuit travelled through Europe, only one text - published in Magdeburg Zeitung on October 21, 1880 - voiced some doubts on the use of zoological gardens for the exposition of human beings, and on the practice of such expositions in general. ${ }^{47}$ The article was discussed in German intellectual circles, and it seems it did not express the majority opinion. At least, Virchow in his lecture on November 7 reacted to it indignantly and defended the current practice of ethnographic shows being done "on behalf of science" (VIRCHOW 1880:270). None of the Czech or German-Bohemian media even hinted at such considerations. It needs to be taken into account that both ethnic groups in the Czech Lands not only aspired to become equal to the most dominant European nations, and were themselves feeling real or imagined contempt towards them, within the general worldview that could be termed "Orientalism" in the widest sense (WOLFF 1994). Thus, they consciously followed the western European way of presenting the "primitives" as inferior to themselves, in order to elevate their status symbolically. While Czechs and German-Bohemians themselves only seldom actually visited foreign lands, and certainly could not dominate their inhabitants, they developed what Ulla Vuorela has termed (for her case of Finland) "colonial complicity". They joined in the hegemonic discourses, in derogatory perceiving, constructing and stereotyping "otherness" in the broad context of modernization, nationalism, and restructuring of power relations in the global context (VUORELA 2009:19-20). A scientific examination of the "savages" and their humiliating exploitation as showpieces helped them to manifest such dominance.

There were some specific groups of non-Europeans that were admired and constructed as virtuous heroes by the Czechs - for example, the North American Indians. ${ }^{48}$ But, during their brief visit Prague in 1880, the Labrador Inuit were pushed into the stereotype of the savage Others. The characteristics attached to them by the press - filthiness, ugliness, lack of rationality - bolstered the self-esteem of readers, increasing their awareness of the contrast between savagery and civilization, as well as the bourgeois ideals of orderliness and rationality. The image of a dying nation did not arouse the sympathy of the spectators, who would project into the pitiful remnants of a once mighty people their own fears of being run over by an enemy nation, but rather bolstered the happy prospect of their own progress. The

47 Quoted by RIVET 2014:60-61.

48 Czech poet Josef Václav Sládek in the 1870s implicitly compared the natives, pushed out of their homes, impoverished and forcibly acculturated, to that of Czech migrants to America, forced by material need to leave their homeland and struggling to maintain their language and culture in an Anglophone environment (see the poem "On the Graves of the Indians" in SLÁDEK 1875:34-35). 
conscious ignorance of the fact that at least one of the two Inuit families shared the intellectual heritage of the Czech Reformation gives further proof to the self-styling of the Czechs, who sought in the "primitives" a counter-image of themselves. The physical examination that replicated the research done in Berlin by the most prominent of German anthropologists confirmed the ability of their Prague German-Bohemian pupils to stand up to international competition and at the same time represented a partial victory in the competition with their Czech counterparts. Altogether, the reactions to the "guests from the Far North" testifies to the collectively voiced ambition of inhabitants of the Czech Lands, both Czech and German speaking, for colonial expansion, even when they lacked any real possibility for any economic or political aspirations in this respect.

\section{Acknowledgements}

The present article is the result of a research project supported by the Grant Agency of the Czech Republic "Evolutionalism, Nationalism and Racism in Czech and Slovak Science (1882-1948): Dialogue between the Social Sciences and Biology" (GA 19-03474S). I would specifically like to thank Filip Herza who first opened for me the theme of ethnographic shows in the Czech Lands and their far-reaching implications for the study of Czech nationalism.

\section{Bibliography}

AMES, Eric (2008): Carl Hagenbeck's Empire of Entertainments. Seattle: University of Washington Press.

[anon.] (1871): History of the Mission of the Church of the United Brethren in Labrador for the Past Hundred Years. London: W. Mallalieu \& Co.

ASH, Mitchell G. - SURMAN, Jan (eds.) (2012): The Nationalization of Scientific Knowledge in the Habsburg Empire, 1848-1918. New York: Springer.

BAEHRE, Rainer (2008): Early Anthropological Discourse on the Inuit and the Influence of Virchow on Boas. In Études/Inuit/Studies 32 (2), pp. 13-34.

BLANCHARD, Pascal - LEMAIRE, Sandrine - DEROO, Éric (eds.) (2012): MenschenZoos: Schaufenster der Unmenschlichkeit. Hamburg: Editions du Crieur Public. 
COHEN, Gary B. (2006): The Politics of Survival: Germans in Prague, 1861-1914. 2nd ed. West Lafayette: Purdue University Press.

DICKINS, Tom (2011): The Czech-Speaking Lands, Their Peoples, and Contact Communities: Titles, Names and Ethnonyms. In Slavonic and East European Review 89 (3), 401-454.

FUDGE, Thomas A. (2010): Jan Hus: Religious Reform and Social Revolution in Bohemia. London: I.B. Tauris.

GLASSHEIM, Eagle (2005): Between Empire and Nation: The Bohemian Nobility, 18801918. In: Pieter Judson, Marsha Rozenblit (eds.): Constructing Nationalities in East Central Europe. New York/Oxford: Berghahn Books, pp. 61-87.

GOUAFFO, Albert (2013): Prince Dido of Didotown and 'Human Zoos' in Wilhelmine Germany: Strategies for Self-Representation under the Othering Gaze. In Eve Rosenhaft, Robbie Aitken (eds.): Africa in Europe: Studies in Transnational Practice in the Long Twentieth Century. Liverpool: Liverpool University Press, pp. 19-33.

GRÉGR, Eduard (1858): O lebkách člověčích vůbec a o slovanských zvláště [On Human Skulls in General and on Slavic in Especial]. In Živa 6 (4), pp. 223-242.

HAMILTON, J. Taylor - HAMILTON, Kenneth G. (1967): History of the Moravian Church, Bethlehem: Moravian Church.

HERBSMEIER, Michael (1994): Schauspiel Europa: Die Außereuropäische Entdeckung Europas im 19. Jahrhundert am Beispiel afrikanischer Texte. In Historische Anthropologie 2 (3), pp. 331-349.

HERZA, Filip (2016a): Anthropologists and Their Monsters: Ethnicity, Body, and Ab/Normality in Early Czech Anthropology. In East Central Europe 43 (1-2), pp. 64-98.

HERZA, Filip (2016b): Black Don Juan and the Ashanti from Asch: Representations of "Africans" in Prague and Vienna, 1892-1899. In Adéla Jůnová Macková, Lucie Storchová, Libor Jůn (eds.): Visualizing the Orient: Central Europe and the Near East in the 19th and 20th Centuries. Prague: Academy of Performing Arts, 95-105.

HERZA, Filip (2018): Imaginace jinakosti a přehlídky lidských 'kuriozit' v Praze v 19. a 20. století [Imagination of Otherness and the 'Freak' Shows in Prague in the $19^{\text {th }}$ and $20^{\text {th }}$ Century]. PhD dissertation. Prague: Charles University.

HOUŽVIČKA, Václav (2016): Czechs and Germans 1848-2004: The Sudeten Question and the Transformation of Central Europe. Prague: Karolinum.

JACOBSEN, Johan Adrian (2014): Voyage with the Labrador Eskimos, 1880-1881, transl. and ed. Hartmut Lutz. Quebec: Polar Horizons. 
JAEGER, Jiři (1963): Šest let mezi Eskymáky [Six Years among the Eskimo]. Prague: Orbis.

KISCH, Egon Erwin (1941): Sensation Fair: Tales of Prague,

(2017): To the Origins of American Archaeology in the Czech Lands: The Case of Julius Nestler. In Ethnologia Actualis 17 (1), pp. 89-106.

KŘížOVÁ, Markéta (2020): Wild Chamacoco' and the Czechs: The Double-Edged transl. Guy Enode. New York: Modern Age Books.

KLÁPŠŤOVÁ, Kateřina (2015): Labrador Moravian Missions and the Czech Collectors of Inuit objects in the Early Twentieth Century. In Annals of the Náprstek Museum 36 (1), pp. 23-44.

KŘíŽ, Bohumír - BENEŠ, Čestmír (2010): Historie výskytu pravých neštovic v českých zemích od poloviny 19. století do současnosti [The History of Smallpox in the Czech Lands from the Mid-19 th $^{\text {th }}$ Century to Date]. In Zprávy epidemiologie a mikrobiologie 19 (1-2), pp. 34-36.

KŘlí̌OVÁ, Markéta Ethnographic Show of Vojtěch Frič, 1908-1909. In Dagnoslaw Demski (ed.): Staged Otherness: Ethnic Shows in Central and Eastern Europe, 18501939. Warsaw, in press.

LEMMEN, Sarah (2013): Noncolonial Orientalism? Czech Travel Writing on Africa and Asia around 1918. In James Hodkinson, John Walker (eds.): Deploying Orientalism in Culture and History: From Germany to Central and Eastern Europe. Rochester: Camden House, pp. 209-227.

LORING, Stephen (1998): In Torgnak's Realm: The Nineteenth-Century Photography of Moravian Missionaries in Labrador. In Johathan H. King, Henrieta Lidchi (eds.): Imaging the Arctic. Seattle: University of Washingon Press, pp. 207-220.

LEMPA, Heikki - PEUCKER, Paul (2010): Introduction. In Heikki Lempa, Paul Peucker (eds.): Self, Community, World: Moravian Education in a Transatlantic World. Bethlehem: Moravian Archives, pp. 15-30.

MAJER, Jiří (1994): Vojta Náprstek a počátky českého průmyslového muzejnictví [Vojta Náprstek and the Beginnings of the Czech Industrial Museum]. In Jan Hozák (ed.): Vojta Náprstek a muzejnictví [Vojta Náprstek and Museums]. Prague: NTM, pp. 15-21.

MEIER, Gudrun (1978). Zur Geschichte des Museums. In Völkerkundemuseum Herrnhut: Außenstelle des Staatlichen Museums für Völkerkunde, Dresden, Dresden: Museum für Völkerkunde, pp. 5-9. 
MURPHY, Daniel (1995): Comenius: A Critical Reassessment of his Life and Works. Dublin: Irish Academic Press.

NEŠPOR, Zdeněk et al. (2010): Náboženství v 19. století: Nejcírkevnější století, nebo obdobi zrodu českého ateismu? [Religion in the 19 $9^{\text {th }}$ century: The Most Religious Century, or the Period of the Birth of Czech Atheism?]. Prague: Scriptorium.

NIPPA, Annegret (2003): Ethnographie und Herrnhutter Mission. Herrnhut: Völkerkundemuseum.

NOVOTNÝ, Vladimír (ed.) (1997): Hospody a pivo v české společnosti [Pubs and Beer in Czech Society]. Prague: Academia.

PALACKÝ, František (1867): Dějiny národu českého v Čechách a v Moravě [History of the Czech Nation in Bohemia and Moravia]. Prague: Friedrich Tempsky.

PÁNEK, Jaroslav - TŮMA, Oldřich et al. (2018): A History of the Czech Lands, transl. Justin Quinn, Petra Key, Lea Bennis. Prague: Karolinum.

RIVET, France (2014): In the Footsteps of Abraham Ulrikab: The Events of 1880-1881, Quebec: Polar Horizons.

ROZHOŇ, Vladimír (2005): Čeští cestovatelé a obraz zámoři v české společnosti [Czech Travellers and the Image of Overseas Regions in Czech society]. Prague: A. Skřivan.

ŘEZNíKOVÁ, Lenka et al. (2014): Figurace paměti: J. A. Komenský v kulturách vzpomínání 19. a 20. století [Figuration of Mmory: J. A. Comenius in Culture of Remembrance of the $19^{\text {th }}$ and $20^{\text {th }}$ Century]. Dolní Břežany: Scriptorium.

SECKÁ, Milena (2011): Vojta Náprstek: Vlastenec, sběratel, mecenáš [Vojta Náprstek: Patriot, Collectioner, Maecenas]. Prague: Vyšehrad.

SECKÁ, Milena (2016): Jen Náprstková, prosím...: Neobyčejný život $v$ dobových pramenech [Just Mrs. Náprstek, Please...: Extraordinary Life in the Sources]. Prague: National Museum.

SECKÁ, Milena - ŠÁMAL, Martin (eds.) (2014): Byl to můj osud...: Zápisky Josefy Náprstkové [It Was My Destiny...: Notes of Josefa Náprstková]. Prague: National Museum.

SLÁDEK, Josef Václav (1875): Básně [Poems]. Prague: Ferd. Dattel.

ŠÁMAL, Martin (2013): Emil Holub: Cestovatel - etnograf - sběratel [Emil Holub: Traveller - Ethnographer - Collector]. Prague: National Museum. 
ŠKERLJ, Božo - BOŽEK, Josef (1952): Jindřich Matiegka and the Development of Czech Physical Anthropology. In American Journal of Physical Anthropology 10 (4), pp. 515-519.

TAYLOR, J. Garth (1981): An Eskimo Abroad, 1880: His Diary and Death. In Canadian Geographic 101 (5), pp. 38-43.

ULRIKAB, Abraham (2005): The Diary of Abraham Ulrikab: Text and Context, transl. and ed. Hartmut Lutz. Ottawa: University of Ottawa Press.

VIRCHOW, Rudolf (1880): Eskimos von Labrador (Ausserordentliche Zusammenkunft im zoologischen Garten am 7. November 1880). In Zeitschrift für Ethnologie 12, pp. 253-274.

VUORELA, Ulla (2009): Colonial Complicity: The 'Postcolonial' in a Nordic Context. In Suvi Keskinen et al. (eds.): Complying with Colonialism: Gender, Race and Ethnicity in the Nordic Region. Farnham: Ashgate, pp. 19-33.

WHITELEY, William H. (1966): The Moravian Missionaries and the Labrador Eskimos in the Eighteenth Century. In Church History 35 (1), pp. 76-92.

WOLFF, Larry (1994): Inventing Eastern Europe: The Map of Civilization in the Mind of the Enlightenment. Stanford: Stanford University Press.

ZANTOP, Susanne (1997): Colonial Fantasies: Conquest, Family and Nation in Precolonial Germany, 1770-1870. Durham: Duke University Press. 
Markéta KŘížoVÁ is Professor at the Centre for Ibero-American Studies at the Faculty of Arts, Charles University. She received her MA in History and Anthropology, and her PhD in IberoAmerican studies at the same faculty and university. She lectures on native cultures of Latin America, colonial history and the methods and techniques of historiography. Her academic interest focus on the history of overseas expansion, the problems of cultural encounters and competitions in the Atlantic world, migrations and cultural transfers, and also intellectual history (including the history of museums). She held a doctoral fellowship at Universidad Autónoma de México, research fellowship at the Ibero-American institute in Berlin (2017), was invited as visiting professor (Cátedra Jan de Vos) to Centro de Investigaciones y Estudios Superiores en Antropología Social in San Cristóbal de Las Casas (Mexico) in 2018. She published, among others, the monographs La ciudad ideal en el desierto: Proyectos misionales de la Compaňía de Jesús y la Iglesia Morava en la América colonial (2004); The Strength and Sinews of This Western World..." (African Slavery, American Colonies and the Effort for Reform of European Society in the Early Modern Era) (2008); and Reyes, emprendedores, misioneros: Rivalidad imperial $y$ sincretismo colonial en la Costa de Mosquitia, siglo XIX (2016).

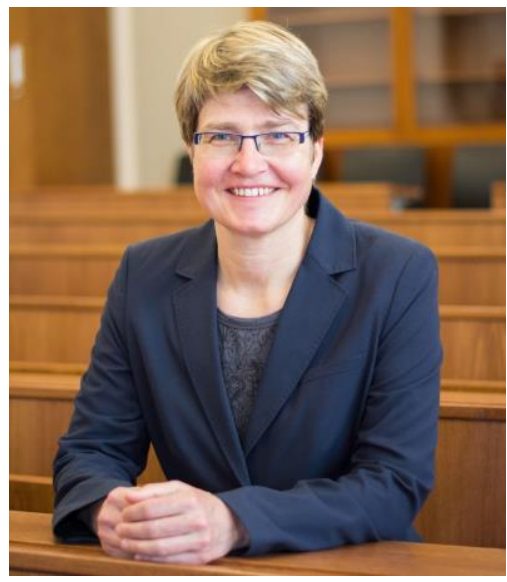

